\title{
TECHNOLOGICAL INNOVATION \\ MANAGEMENT: CASE STUDY WITH ENTERPRISES IN THE \\ PEANUT-PROCESSING SECTOR
}

\author{
Depieri, Heitor Augusto ${ }^{1}$ \\ Batalha, Mário Otávio²
}

Recibido: 22/03/2020 Revisado: 02/08/2020 Aceptado: 03/09/2020

\begin{abstract}
Technological innovations are the basis of the development of new products, production processes, and business formats, contributing decisively to the success of contemporary business strategies. Recognition of the importance of this issue to the development of enterprises and regions has been reflected in an array of studies and theoretical models seeking to improve technological innovation management in organizations. The present study is part of this context. Based on a broad literature review, it uses knowledge about technological innovation management to propose and test a theoretical analytical framework to evaluate and contribute to the improvement of the innovation management process in manufacturing enterprises. The various theoretical constructs used to create the proposed analytical framework address aspects specific to the success of the technological innovation process. Although it is important to deepen the focal point prioritized by the constructs in their analysis, by focusing on specific factors, they can bias the manager's perspective or hinder a more holistic and complete view of the problem. The proposed framework was tested using three case studies in the peanut agrifood business in the State of São Paulo, Brazil. Main results show that it was capable of capturing the differences in how the studied enterprises carried out technological management. The three companies were classified into one of two groups. The first prioritized process innovation, which responds to direct stimuli from the companies that purchase their product. These companies do not sell directly to end consumers but to other processing companies. The second group privileged product innovation guided by the demands of the final consumer market. The analyses carried out provide data to establish technological management processes adapted to the competitive strategies of the investigated organizations.
\end{abstract}

Key words: Technological innovations, business strategies, analytical framework, peanut, agrifood industry, technological management, Sao Paulo, Brazil

\footnotetext{
${ }^{1}$ Bachelor Degree in Agribusiness (Faculdades de Tenologia do Estado de São Paulo-FATEC, Brazil); Master's Degree in production Engineering from the Agro-industry Study and Research Group-GEPAI (Universidade Federal de São Carlos-UFSCar, Brazil). Consultant for different companies in the agribusiness sector in Brazil. Postal address: Rod. Washington Luiz, s/n. São Carlos / SP / Brasil - CEP 13565 905. Phone: +55 163351 9537; email: heitordepieri@gmail.com

${ }^{2}$ Bachelor Degree in Chemical Engineering (Universidade Federal de Santa Catarina-UFSC, Brazil); Master's Degree in Production Engineering (UFSC, Brazil); Ph.D. in Ingénierie des Systèmes Industriels (Institut National Polytechnique de Lorraine-INPL, France). Full Professor at the Department of Production Engineering of the Universidade Federal de São Carlos (UFSC, Brazil). Postal address: Rod. Washington Luiz, s/n. São Carlos / SP / Brasil - CEP 13565 905. Phone: +55 163351 9537; e-mail:dmob@ufscar.br
} 


\section{RESUMEN}

Las innovaciones tecnológicas son la base del desarrollo de nuevos productos, procesos de producción y formatos comerciales, que contribuyen así de manera decisiva en el éxito de las estrategias comerciales contemporáneas. El reconocimiento de la importancia de este factor para el desarrollo de las empresas y las regiones se ha reflejado en una serie de estudios y modelos teóricos que tratan de mejorar la gestión de la innovación tecnológica en las organizaciones. El presente estudio se inscribe en este contexto. Basándose en un amplio examen de la bibliografía, utiliza los conocimientos sobre la gestión de la innovación tecnológica para proponer y poner a prueba un marco analítico teórico que permita evaluar y contribuir a la mejora del proceso de gestión de la innovación en las empresas manufactureras. Las diversas construcciones teóricas utilizadas para crear el marco analítico propuesto abordan aspectos específicos del éxito del proceso de innovación tecnológica. Aunque es importante profundizar en el punto focal priorizado por los constructos en su análisis, al centrarse en factores específicos pueden sesgar la perspectiva del gestor o bien dificultar una visión más holística y completa del problema. El marco propuesto se probó utilizando tres estudios de caso en el sector agroalimentario del maní en el estado de São Paulo (Brasil). Los principales resultados revelaron que dicho marco fue capaz de captar las diferencias en la forma en que las empresas estudiadas llevaban a cabo la gestión tecnológica. Las tres empresas se clasificaron en uno de dos grupos. El primero priorizó la innovación de procesos, que responde a estímulos directos de las empresas que compran su producto. Estas empresas no venden directamente a los consumidores finales, sino a otras empresas de procesamiento. El segundo grupo privilegió la innovación de productos, guiada por las demandas del mercado de consumidores finales. Los análisis realizados proporcionan datos para establecer procesos de gestión tecnológica adaptados a las estrategias competitivas de las organizaciones investigadas.

Palabras clave: innovaciones tecnológicas, estrategias empresariales, marco analítico, maní, cacahuete, industria agroalimentaria, gestión tecnológica, Sao Paulo, Brasil

\section{RÉSUMÉ}

Les innovations technologiques sont à la base du développement de nouveaux produits, des processus de production et des modèles d'affaires, contribuant de manière décisive au succès des stratégies commerciales contemporaines. La reconnaissance de l'importance de cette question pour le développement des entreprises et des régions résultent dans une série d'études et de modèles théoriques visant à améliorer la gestion de l'innovation technologique dans les organisations. Cet article s'inscrit dans ce contexte. Sur la base d'une revue approfondie de la littérature, il utilise les connaissances disponibles sur la gestion de l'innovation technologique pour proposer et tester un cadre analytique théorique capable d'évaluer et de contribuer à l'amélioration du processus de gestion de l'innovation dans les entreprises manufacturières. Les différents concepts théoriques utilisés pour créer le cadre analytique proposé réunissent les principaux facteurs responsables du succès du processus d'innovation technologique. Le modèle théorique présenté a été testé à l'aide de trois études de cas dans le secteur agroalimentaire de la transformation de l'arachide dans l'État de São Paulo, au Brésil. Les principaux résultats ont révélé que ledit cadre était capable de saisir les différences dans la manière dont les entreprises étudiées menaient la gestion des technologies. Les trois sociétés ont été classées dans l'un de ces deux groupes.

Le premier a donné la priorité à l'innovation de procédé, qui répond aux stimuli directs des entreprises qui achètent son produit. Ces entreprises ne vendent pas directement aux consommateurs finaux, mais à d'autres entreprises de transformation. Le deuxième groupe a privilégié l'innovation produit, guidée par les demandes du marché de consommation finale. Les analyses réalisées fournissent des données pour mettre en place des processus de gestion technologique adaptés aux stratégies concurrentielles des entreprises étudiées.

Mots-clés : Innovations technologiques, stratégies commerciales, cadre analytique, arachide, industrie agroalimentaire, gestion technologique, Sao Paulo, Brésil 


\section{RESUMO}

Inovações tecnológicas estão na base do desenvolvimento de novos produtos, processos de produção e formatos de negócio, contribuindo decisivamente para o sucesso das estratégias empresariais contemporâneas. O reconhecimento da importância desta problemática para o desenvolvimento de empresas e regiões tem se refletido na criação de uma diversidade de estudos e modelos teóricos voltados à busca de melhorias na gestão da inovação tecnológica nas organizações. Este trabalho insere-se neste contexto. Calcando-se em uma ampla revisão bibliográfica, ele se apropria de conhecimentos sobre gestão da inovação tecnológica disponíveis na literatura para propor e testar um quadro analítico teórico que permita avaliar e contribuir para a melhoria do processo de gestão da inovação em empresas de transformação. Considera-se que os vários construtos teóricos utilizados na formulação do quadro analítico proposto tendem a abordar aspectos específicos ao sucesso do processo de inovação tecnológica. Embora isto seja importante para aprofundar o ponto focal que os construtos privilegiam em suas análises, ao centrar em fatores específicos, eles podem desviar a visão do gestor ou encobrir uma visão mais holística e completa do problema. O modelo analítico proposto, complementando e enriquecendo os trabalhos encontrados na literatura, considera diversos modelos e perspectivas para entender onde estão concentrados os esforços de inovação nesse setor. $\mathrm{O}$ framework proposto foi testado em três estudos de caso do setor agroalimentar do amendoim do Estado de São Paulo. Os resultados mostraram que ele foi capaz de captar as diferenças na maneira como as empresas pesquisadas realizavam a gestão tecnológica. A aplicação do quadro analítico proposto identificou que as empresas ditas de segunda transformação investem em inovações de processo, ao passo que as que atendem diretamente o mercado consumidor (agroindústrias de terceira transformação) priorizam inovações de produto. As análises efetuadas forneceram subsídios ao estabelecimento de processos de gestão tecnológica adaptados às estratégias competitivas das organizações investigadas.

Palavras-chaves: inovações tecnológicas, estratégias empresariais, framework analítico, indústria agroalimentar, gestão tecnológica, amendoim, São Paulo, Brasil

\section{INTRODUCTION}

The role of technological innovation in organizational performance has been widely explored in the literature (Ali, Kan \& Sarstedt, 2016; Azar \& Ciabuschi, 2017; Camisón \& Villar-López, 2014; Saunila, Pekkola \& Ukko, 2014). Researchers in the field point to a positive correlation between the success of an organization and its innovative capacity (Freeman \& Soete, 1997; Martín-de-Castro, 2015; Koc \& Ceylan, 2007; Zhou, Yim \& Tse, 2005). This is why the identification and evaluation of actions and factors that favor or hinder innovation in organizations are among the main interests of contemporary researchers and administrators.

Innovation can be a result of strategies to obtain technology from external agents (suppliers, research institutes, universities, etc.) (Fischer, Schaeffer \& Vanortas, 2018; Goedhuys \& Veugelers, 2012; Guan, Mok, Yam, Chin \& Pun, 2006; Liefner, Si \& Schäfer,
2019) or in-house development efforts, i.e., «inventive» or innovative» efforts (GarcíaManjón \& Romero-Merino, 2012; Lee, Wu \& Pao, 2014). These two technological strategies (endogenous or exogenous development) include various factors that condition the likelihood of their success or failure. All organizations have technological capacities (De Mori, 2012), some more or less explicit or planned, that are a result of adopting thirdparty technologies (an exogenous strategy) and/or mobilizing internal resources (an endogenous strategy), especially those related to infrastructure, personnel, and organizational resources. Regardless of the technological strategy followed and adopted, the ultimate objective of the efforts made by organizations in the technological development area is to develop or strengthen their competitive position through product, process, and management innovation (Martín-de-Castro, Delgado-Verde, Navas-López \& Cruz- 
González, 2013; Pisano, 2015; Slater, Mohr \& Sengupta, 2014; Tidd \& Bessant, 2015).

The innovation management process is very complex and uncertain in terms of means and results because of various factors. These characteristics of the innovative process highlight the importance of adopting management mechanisms that involve practices relative to strategic planning, incentives for leadership and entrepreneurship, market relations, and investment assessment and selection, among others (Dziura, 2001; Han, Kim \& Srivatava, 1998; Zornoza, Alcamí, Ciprés \& Navarro, 2004). It is through successful innovation that organizations can gain competitive advantages in managerial areas because of initiatives such as these and others.

To contribute to this discussion, the present study used parts of existing innovation management constructs and models in the literature to propose and test a theoretical analytical framework to evaluate and contribute to the improvement of the innovation management process in manufacturing enterprises. This analytical framework was tested in three peanut agrifood companies in the State of São Paulo, Brazil. These companies were chosen because they were the largest peanut producers and processors in the State of São Paulo at the time of data collection. Furthermore, as will be described below, they adopted different corporate strategies, which allowed the researchers to verify the framework's ability to capture these differences.

\section{THE SYSTEMIC APPROACH AND INNOVATION IN ORGANIZATIONS}

The first integrated management approaches to innovation emerged in the 1990s and early 2000s. This was when Bulgerman, Maidique \& Wheelwrights (2001), Tidd, Bessant \& Pavitt (2005), and Tushman, Anderson \& O’Reilly, (1997) developed and proposed systemic and procedural approaches to technological innovation management.

According to these lines of thought, Singuaw, Simpson \& Enz, (2006) considered that the technological management process included a set of factors and actions that expanded on the classic analytical process of observing cause and effect in the technological innovation of organizations. Also based on this multifaceted view of technological management, and guided by the works of Tidd et al. (2005), Davis \& Hobday (2005), Dodgson (2000), Ganguly (1999) and Quadros (2008) developed a technological innovation management model, combining three analytical dimensions: i) processes and tools; ii) governance and organization; and, iii) resources allocated by companies to innovation. These studies show how the current theoretical models began to point to new variables and different perspectives of analysis that would result in new theoretical constructs capable of explaining and contributing to the technological management process of organizations. Therefore, this is an area of knowledge that is still under construction and that seeks to understand how institutions, from the organizational point of view, mobilize resources to innovate; and how, in turn, these innovations can reflect in the definition and implementation of these organizations' competitive strategies.

\subsection{INNOVATION MANAGEMENT IN ORGANIZATIONS}

Studying innovation management from different theoretical perspectives broadens the possibilities of identifying a diverse set of factors that can influence the generation, dissemination, and adoption of technologies in organizations. The following sections will briefly discuss the theoretical constructs used in the framework proposed in this article.

\subsubsection{INFRASTRUCTURE}

Physical infrastructure plays a key role in the development of new technologies and innovations. Depending on the type of company and sector in which they operate, in-house or third-party research and development (R\&D) labs (Dahlander \& Gann, 2010; Schot \& Steinmueller, 2018) or even pilot plants (Frishammar, 2018; Palage, Lundmark \& Söderholm, 2019), can be a crucial factor for developing innovation. However, it is not enough for companies to 
have such facilities. They must also develop innovative activities that are aligned with the organizations' strategic and tactical objectives (Quadros, 2008), which implies coordinating the technological management activities of companies.

\subsubsection{COORDINATION}

Hill \& Neely (2000) defended the proposition that innovation is the result of the work of collaborators at all operational levels. However, it is the role of managers to map the opportunities present in the market in order to translate them into innovation (Deschamps \& Nelson, 2014; OCDE, 1994). Furthermore, managers must coordinate the efforts of the company's different sectors in various technological management activities. It is up to the managerial body to conduct the process of creating new ideas, ensuring a favorable environment for transforming ideas into innovation (Deschamps \& Nelson, 2014; King \& Anderson, 2002).

\subsubsection{FINANCIAL RESOURCES}

The success of innovation projects depends on the adequate allocation of the necessary financial resources (Hoegl, Gibbert \& Mazursky, 2008; Singuaw et al., 2006) for its execution. For example, establishing financial incentives to reward internal activities associated with innovation can play a decisive role in the success of the organization's technological strategy (Amabile \& Pratt, 2016; Gupta \& Singhal, 1993; Janssen, 2000; Loof \& Hesmati, 2002). Tidd \& Bessant (2015) said that, in general, the successful allocation of resources devoted to innovation results in innovation-guided organizational processes that are clear and well established.

\subsubsection{PERSONAL SKILLS}

Studies show the importance of the skills of individuals in innovative organizations (Jarvis \& Prais, 1995; Pfeffer, 1994). These skills, when coupled with organizational learning mechanisms (Llórens-Montes, García-Morales \& Verdú-Jover, 2004) and efficient professional development policies, promote initiative and result in commitment to innovation (Huselid, 1995). Development and training are important so that people are able to create a sense of responsibility and initiative (Tidd \& Bessant, 2015). This initiative enables autonomy in decisionmaking and autonomy by collaborators.

\subsubsection{TEAM INTEGRATION}

The successful adoption of new technologies, from the managerial point of view, requires that collaborators be prepared to receive these new technologies. It is necessary to clarify the views behind, the objectives of, and the need for adopting a given technology. This process is called cross-functional acclimation by Singuaw et al. (2006). This term refers to the interaction, common beliefs, and understandings crossing all functional areas with only one goal: innovation. Tidd \& Bessant (2015) suggest that this integration of teams from different sectors is interconnected with and contributes to the following:

- Team integration: Reducing the time of new product development;

- Internal performance: In general, companies perform better in transactions and contribute more to revenue for creating new products; and,

- Flexibility: Innovative companies are also inclined to use these team structures in less innovative projects (process improvement, for example).

The perception of intersectoral integration stimulates an environment in which individuals have the ability to be flexible and solve problems. To this end, decision support tools must also be used. These tools can be models, prototypes, and information technology that integrate all company areas involved in innovative processes (Singuaw et al., 2005).

\subsection{THE PROPOSED ANALYTICAL FRAMEWORK}

The six constructs exhibited above were used to construct the analytical framework proposed and used in this article. Each of the proposed constructs will be explored in the case studies that compose the empirical part of this article. The use of physical infrastructure is essential in organizations 
Table 1

Summary of authors and constructs

\begin{tabular}{|c|c|c|c|c|c|c|}
\hline & Infrastructure & Coordination & $\begin{array}{l}\text { Financial } \\
\text { resources }\end{array}$ & $\begin{array}{l}\text { Personal } \\
\text { skills }\end{array}$ & $\begin{array}{c}\text { Team } \\
\text { integration }\end{array}$ & $\begin{array}{c}\text { Technology } \\
\text { absorptive } \\
\text { capacity }\end{array}$ \\
\hline Dahlander \& Gann (2010) & $x$ & & & & & $x$ \\
\hline Schot \& Steimueller (2018) & $x$ & & & & & $x$ \\
\hline Fishammar (2018) & $x$ & & & & & \\
\hline $\begin{array}{l}\text { Palage, Lundmark \& Söderholm } \\
\text { (2019) }\end{array}$ & $x$ & $x$ & & & & \\
\hline Quadros (2008) & $x$ & $x$ & & & & \\
\hline Hill \& Neely (2000) & & $x$ & & & $x$ & \\
\hline Deschamps \& Nelson (2014) & & $x$ & & & & \\
\hline OECD (1994) & $x$ & $x$ & & & & $x$ \\
\hline King \& Anderson (2002) & & $x$ & & $x$ & $x$ & \\
\hline Hoegl, Gibbert \& Mazursky (2008) & & & $x$ & $x$ & $x$ & \\
\hline Singuaw , Simpson \& Enz (2006) & & & $x$ & $x$ & $x$ & \\
\hline A mabile \& Pratt (2016) & & & $x$ & $x$ & $x$ & \\
\hline Gupta \& Singhal (1993) & & & $x$ & $x$ & & \\
\hline Janssen (2000) & & & $x$ & & $x$ & $x$ \\
\hline Loof \& Hesmati (2002) & $x$ & & $x$ & & & $x$ \\
\hline Jarvis \& Prais (1995) & & & & $x$ & & \\
\hline Pfeffer (1994) & & $x$ & $x$ & $x$ & & \\
\hline $\begin{array}{l}\text { Llórens-Montes, García-Morales } \\
\text { \& Verdú-Jover (2004) }\end{array}$ & & $x$ & & $x$ & & $x$ \\
\hline Huselid (1995) & & $x$ & $x$ & $x$ & $x$ & \\
\hline Tidd \& Bessant (2015) & & & $x$ & $x$ & $x$ & $x$ \\
\hline Quandt \& Castilho (2017) & & $x$ & & $x$ & $x$ & $x$ \\
\hline Cohen \& Levinthal (1990) & & $x$ & & $x$ & & $x$ \\
\hline Zheng (2011) & & & $\mathrm{x}$ & & & $x$ \\
\hline
\end{tabular}

Source: Created by the authors

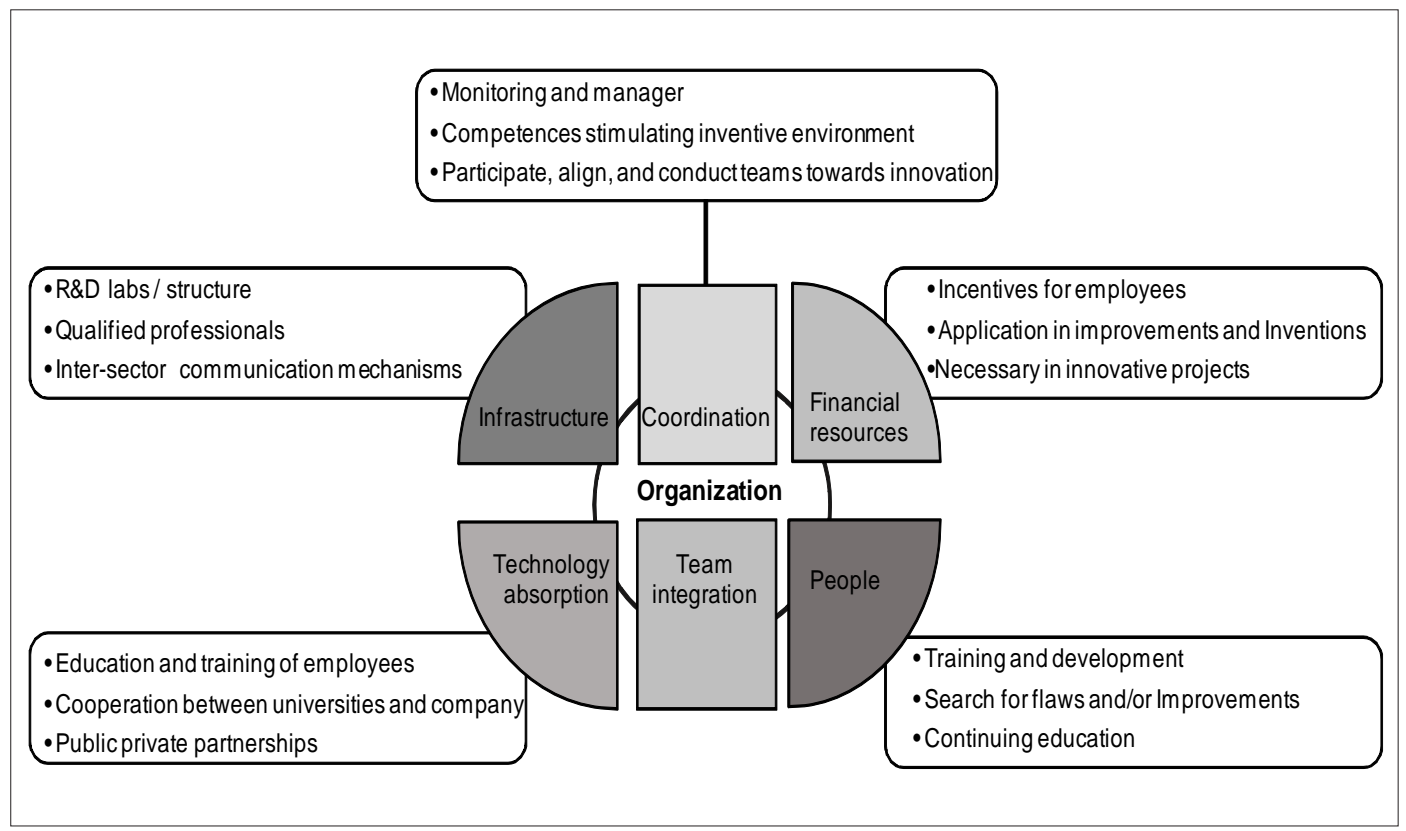

Figure 1. Determining factors for technological management. Source: Created by the authors 
that desire product innovation; furthermore, managers must coordinate these resources, in line with the correct allocation of existing financial resources to this end, using qualified individuals to implement technologies and ensure a favorable environment for technological absorption. These competencies are summarized in Figure № 1 . As stated before, the proposed framework gathered concepts and models applied to innovation management from different theoretical matrices. Thus, each model of analysis consulted contributed elements to the construction of this article's analytical model. If on the one hand this theoretical construction loses in depth regarding the study of specific aspects of innovation management, on the other hand it gains in breadth and in the systemic nature of the analyses.

It is important to note that the analytical framework proposed in this study is different because it systematizes and aggregates the main theoretical constructs associated with technological innovation management at the organizational level. The different models studied here tend to address aspects that are specific but central and important to the success of the technological innovation process. Although it is important to deepen the focal point prioritized by the constructs in their analysis, focusing on specific factors can bias the manager's perspective or hinder a more holistic and complete view of the problem.

\section{RESEARCH METHOD}

This was a qualitative and exploratory study based on case studies. Thus it did not attribute metric values to the studied variables nor did it use statistical methods. Existing models, concepts, and theories were identified and examined in light of the study's interests. This analytical exercise resulted in the identification of variables of analysis that were combined into the proposed framework. This framework was tested in the case studies conducted in the field research.

The case studies were carried out in peanutprocessing companies in the State of São Paulo. In 2018, this State was responsible for $89 \%$ of all of Brazil's peanut production (CONAB, 2018). The companies were chosen for convenience, although it is important to highlight that the three studied enterprises are the largest peanut processors in São Paulo.

An interview script was used as the data collection instrument. Together with the interviews, observations were added based on the perceptions of the researchers, in addition to document analyses. In all, six interviews were conducted in the three enterprises. The positions of the individuals ranged from managers in the areas of innovation, agricultural production process, and quality up to supervisors in the same fields.

\subsection{CHARACTERISTICS OF THE COMPANIES THAT PARTICIPATED IN THE CASE STUDIES}

Company «A» is one of the main companies in the crude peanut oil processing and export sector in Brazil. Its main activity is exporting crude peanut oil to European and Asian countries. In 2004, it went through a restructuring and remodeling process, resulting in the modernization and expansion of its facilities. Currently, it is responsible for the production of 420 tons of crude peanut oil per year.

Company «B» began its activities in 1963, with the merger of sugarcane producers; however, peanut-related activities only began in 1984. It began exporting the product in 2000. The brand was consolidated in 2011, when the company invested in the quality and expansion of its processing plant.

Company "C» operates in the peanutderived confection segment. Founded in 1942, it began producing candy to be sold by street vendors and small local stores. Currently, it is recognized as one of the largest companies specializing in peanut-derived products in the country. The company has developed new products, processes, and innovative packaging.

The three studied enterprises can be classified as large and medium, according to the criteria used by the Brazilian Institute of Geography and Statistics (IBGE, 2015) (see Table № 2). This Table also presents a summary of the characteristics with the number of factories and employees at these companies.

Companies A and B are considered firsttransformation agro-industries, i.e., they are 
Table 2

Characteristics of the studied companies

\begin{tabular}{llclc}
\hline & Size & $\begin{array}{c}\text { Number of } \\
\text { plants }\end{array}$ & Product & $\begin{array}{c}\text { Number of } \\
\text { e m ploye s }\end{array}$ \\
\hline Company "A" & Large & 4 & Crude peanut oil & 500 \\
Company "B" & Medium & 6 & In natura peanut processing & 440 \\
Company "C" & Large & 2 & Peanut-based sw eet and salty confectionery & 1,4 \\
\hline
\end{tabular}

Source: Created by the authors

directly associated with agricultural production and, above all, their main clients are other industries, whether food-related or not. Company $\mathrm{C}$ can be defined as thirdtransformation agro-industry and, as such, its production, distribution, and sales characteristics are different from those of companies $\mathrm{A}$ and $\mathrm{B}$. One such striking difference is Company C's direct contact with the end consumer. First-transformation agroindustries are upstream in the production chain, while third-transformation ones are downstream. This position in the production chain strongly impacts the companies' competitive strategies, among them their technological strategies. This article will show that the proposed model was capable of identifying these differences in technological strategies according to the characteristics of the studied companies.

\section{DISCUSSION OF RESULTS}

The information collected allowed the researchers to carry out intra and inter-case assessments. The proposed analytical framework guided the interviews and was the basis for constructing is showed in Table $\mathrm{N}^{\mathrm{o}}$ 3 . This Table defines the characteristics of the innovation management of the three companies and assesses each company's competencies regarding the indicated factors.

Companies A and B prioritized process innovation, resulting in the highest number of innovation cases for the company and not in disruptive market innovation. Their technological management processes were not very formalized and were peripheral in the context of the organizations. In turn, the structures of company $\mathrm{C}$ were more aimed at innovation processes of more formalized and active products, revealing that it adequately mobilized a great number of the factors identified in the theoretical constructs as being positive for technological innovation.

Another aspect that is noteworthy is that processing companies $\mathrm{A}$ and $\mathrm{B}$ did not have relationships or partnerships with companies in the same sector, i.e., they did not have horizontal integration processes. This may be the result of a situation in which these companies compete directly for the same buyers, especially those located in other countries. Therefore, the partnerships made by these companies (A and B) were frequently associated with the acquisition or common development of new machinery by supplying companies, which provide these institutions with new technologies. In turn, company $\mathrm{C}$ developed partnerships with other companies in the food segment with the goal of implementing and producing new products. Having identified and assessed the factors important to innovation in the case studies using the framework, it is important to go back to the elements found in the literature and to assess them in relation to the empirical and theoretical findings of the study. Table № 3 summarizes the elements suggested by the literature for the purposes of this assessment. It shows that eight of the twelve factors considered in the literature as important to innovation were identified, to a greater or lesser intensity, in all of the companies included in the field study. These factors were as follows:

1. Allocating resources specific to innovation;

2. Integrating of different sectors to achieve innovative practices; 
Table 3

Summary of the competencies found in the case studies according to the proposed model

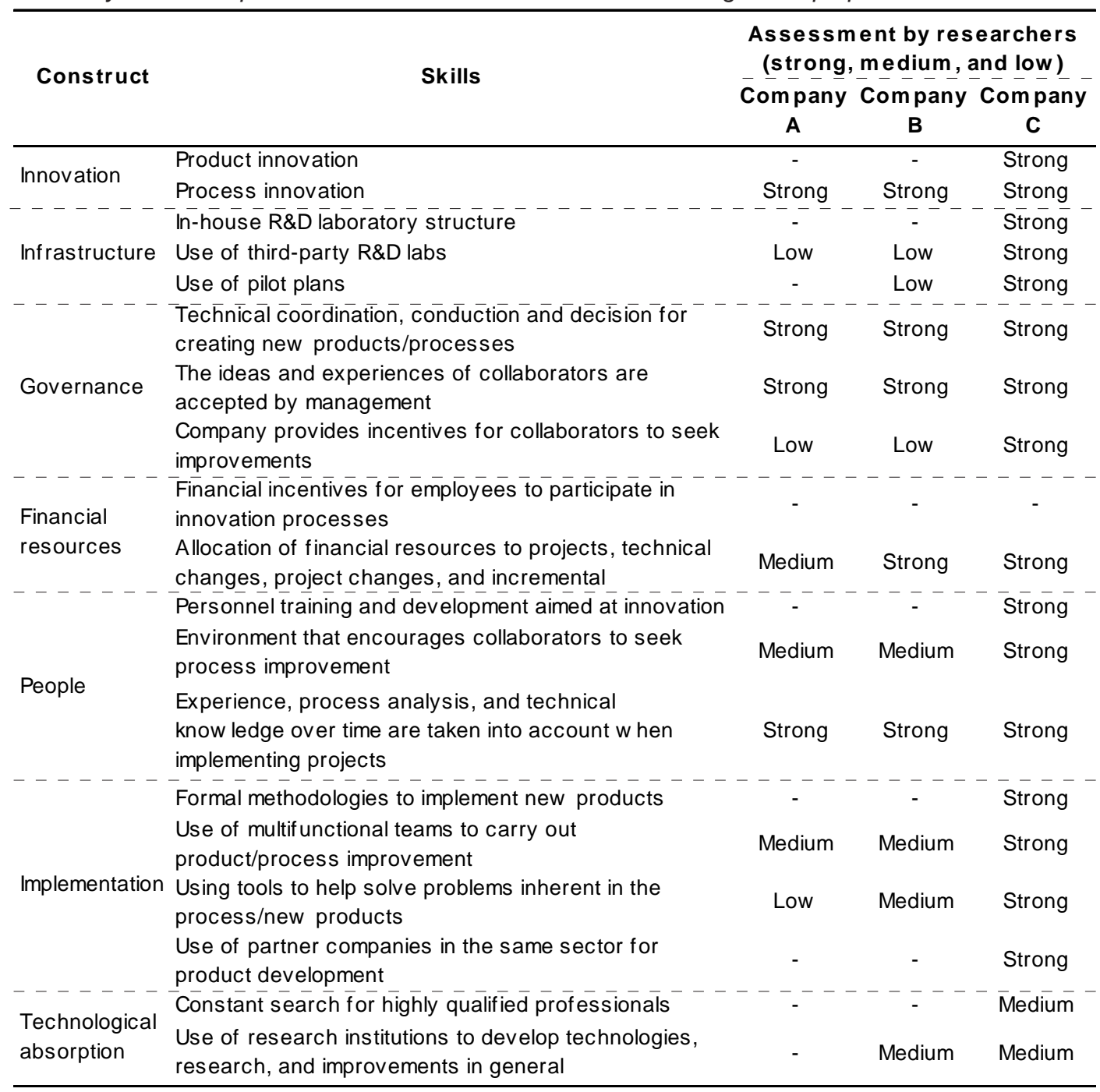

Source: Created by the authors

3. Coordinating, conducting, and deciding on projects aimed at improvement;

4. Incentivizing the generation of new ideas;

5. Resource allocation in improvement projects;

6. Including technical knowledge of collaborators in innovation projects;

7. Using formal methodologies to develop new products/processes and integrating teams and other sectors; and,
8. Using external sources as a form of technological absorption.

\section{CONCLUSIONS}

The goal of this study was to propose an analytical assessment framework for technological management. The results show

analyzed companies. The framework identified the companies' decision-making processes (Deschamps \& Nelson, 2014; 
Table 4

Factors important to technological management: Results of applying the theoretical analytical framework suggested in the case studies

$\begin{array}{ccc}\begin{array}{c}\text { Aspects found in the } \\ \text { literature }\end{array} & \text { Authors } & \begin{array}{c}\text { Relationship between theory and practice in the } \\ \text { enterprises }\end{array}\end{array}$

\begin{tabular}{ll}
\hline & $\begin{array}{l}\text { Quadros (2008); A mabile \& Pratt } \\
\text { (2016); Gupta \& Singhal (1993); } \\
\text { Japacity to integrate }\end{array}$ \\
$\begin{array}{l}\text { individuals into the } \\
\text { various sectors to meet } \\
\text { objectives }\end{array}$ & $\begin{array}{l}\text { Singuaw et al. (2005); Tidd \& Bessant } \\
(2015)\end{array}$
\end{tabular}

Dahlander \& Gann (2010); Silva (2016); Schot \& Steinmueller (2018)

Capacity to maintain R\&D Hill \& Neely (2000); Quadros (2008) lab infrastructure

All three companies allocated specific resources to innovation (financial, professional, managerial, structural, etc.)

Because of the management models adopted and because of the indicators presented in managerial meetings, the three companies used metrics to gauge the integration of its different sectors

In companies $A$ and $B, \bar{R} \& \bar{D}$ labs and infrastructure were devoted to the improvement of processes and machinery. Product innovation $\mathrm{w}$ as found in company $\mathrm{C}$

All of the companies, because of their management models and client specifications, devoted formalized and coordinated efforts to conduct project improvement

In companies $A, B$, and $C$, because of their management models (quality management in the first tw o and innovation management in the third), the managers are responsible for ensuring the direction and use of available resources (1993); Janssen (2000); Loof \& Hesmati (2002); Tidd \& Bessant (2015)

Managers employ

consistent mechanisms to Deschamps \& Nelson (2014); King \& develop new ideas

In all of the researched companies, managers $w$ ere the suppliers of consistent and functional mechanisms to generate ideas from different areas and people (dynamics, bonuses, rew ards, etc.)

In $\overline{\text { general, }}$ all the companies $\bar{w}$ ere incline $\overline{\text { co }}$ to $\overline{\text { maximize }}$ aw areness and use of resources aimed at improvement, considering that they were constantly striving to reduce costs, increase quality as demanded by clients, reduce errors, etc.

Regularly allocates part of Hoegl et al . (2008); Singuaw et al. resources to improvement (2006) projects

Provides training and encouraging personal and professional development

Hill \& Neely (2000); Jarvis \& Prais (1995); Pfeffer (1994) In general, the companies were interested in their collaborators; how ever, only companies $B$ and $C$ had policies for professional training and tertiary education

Regularly includes the experiences, technical know ledge and critical operational analyses of collaborators into projects

Llórens-Montes et al . (2004); Garvin (1993)

Formal methodologies to develop new products and the use of multifunctional teams $w$ ith the help of tools that integrate all the sectors

Singuaw et al . (2006); Tidd \& Bessant

(2015); Gatignon \& Xuereb (1997)

integrate all the se

Searches and uses technical know ledge from sources outside the enterprise (public and private)

Guldbrandsen \& Smeby (2005); Tidd \& Bessant (2015)

Salles \& Bonacelli (2010); Avermaete et al. (2004)
All the companies used the experiences and lessons learned in their operations and processes, and they frequently w orked w ith performance assessment criteria for collaborators from different operational levels

In general, companies A and B w orked w ith tools that integrated the different sectors to improve pre-established metrics. In terms of the development of new products, only company $\mathrm{C}$ used formal creation and implementation methodologies. It also gathered individuals into an innovation center that integrated people from different sectors $w$ ith the same objective: to innovate

All the companies used third-party labs and technologies $w$ hen they did not have the know -how or when it $w$ as not the company's main objective

$\overline{\text { All }}$ the companies w ere receptive to qualified professionals $w$ hen necessary. How ever, in practice, the search for highly trained professionals to deal w ith innovation w as restricted to company $\mathrm{C}, \mathrm{w}$ hich constantly w orked on product innovation

Source: Created by the authors 
OCDE, 1994; Tidd \& Bessant, 2015), organization and learning (Llórens-Montes et al., 2004), use of specialized labor (Jarvis \& Prais, 1995; Pfeffer, 1994) and technological absorption from external sources (Quandt \& Castilho, 2017; Cohen \& Levinthal, 1990; Tidd \& Bessant, 2015; Zheng, 2011), all features considered by the companies to be very relevant to the technological management process.

The case studies showed how this sector develops product, process, and management innovation and also how management works to develop such innovation. Within this sector, the three companies were classified into one of two groups. The first prioritized process innovation, which responds to direct stimuli from the companies that purchase their product. These companies do not sell directly to final consumers but to other processing companies. The second group privileged product innovation guided by the demands of the final consumer market. In fact, product innovation occurred mainly in industries that supply final consumers. Final products usually have many attributes that can be more easily subject to technological innovation (new flavors, packaging, positioning, forms of distribution, etc.). Thus, as shown in the literature (Batalha \& Silva, 2009), the position of agro- industry in the production chain influences its technological management. Agro-industries in the upstream part of agro-industrial production chains tend to privilege process innovation, while companies in the downstream part privilege product innovation.

The proposed analytical framework was useful in identifying, for example, that companies with different markets or strategies invest in equally different innovation-guided skills. Changes in market and product strategies impact technological management strategies. The framework helps decision-makers to visualize what factors and skills must be prioritized to successfully carry out the necessary technological changes. In other words, it shows which investments should be made to increase this change's chance of success.

Finally, it is important to mention some limitations of the present study. Considering this was a qualitative investigation based on case studies, its conclusions cannot be generalized. A higher number of cases would enrich the conclusions of this article and, eventually, enrich the framework with new reflections and variables. It would have also been desirable to have conducted more interviews in each company. Unfortunately, as has been increasingly common, the access of researchers to companies is hindered by obstacles of all sorts.

\section{ACKNOWLEDGMENTS}

We would like to thank the Coordination for the Improvement of Higher Education Personnel (CAPES) for its financial incentive and aid for this study.

\section{REFERENCES}

Ali, M., Kan, K. A. S., \& Sarstedt, M (2016).

Direct and configurational paths of absorptive capacity and organizational innovation to successful organizational performance. Journal of Business Research, 69(11), 5317-5323. doi: https://doi.org/ 10.1016/j.jbusres.2016.04.131

Amabile, T. M., \& Pratt, M. G (2016). The dynamic componential model of creativity and innovation in organizations: Making progress, making meaning. Research in Organization Behavior, 36, 175-177. doi: https:// doi.org/10.1016/j.riob.2016.10.001

Avermaete, T., Viaene, J., Morgan, E. J., Pitts, E., Crawford, M., \& Mahon, D. (2004). Determinants of product and process innovation in small food manufacturing firms. Trends in Food Science \& Technology, 15(10), 474-481. doi: https://doi.org/ 10.1016/j.tifs.2004.04.005 
Azar, G., \& Ciabuschi, F. (2017). Organizational innovation, technological innovation, and export performance: The effects of innovation radicalness and extensiveness. International Business Review, 26(2), 326-327. doi: https://doi.org/10.1016/j.ibusrev.2016.09.002

Batalha, M. O., \& Silva, A. L. (2009). Gerenciamento de sistemas agroindustriais: definições e correntes metodológicas. In $\mathrm{M}$. O. Batalha (Ed.), Gestão agroindustrial (pp. 215). São Paulo: Atlas.

Bulgerman, S. L., Maidique, M. A., \& Wheelwrights, S. (1995). Product development: Past research, present findings and future directions. Academy of Management Review, 20(2), 345-377.

Camisón, C., \& Villar-López, A. (2014). Organizational innovation as an enabler of technological innovation capabilities and firm performance. Journal of Business Research, 67(1), 2891-2902. doi: https://doi.org/ 10.1016/j.jbusres.2012.06.004

Christensen, C. M., \& Bower, J. L. (1996). Customer power, strategic investment, and the failure of leading firms. Strategic Management Journal, 17(3), 197-218. doi: http:// www.jstor.org/stable/2486845

Cohen, W. M., \& Levinthal, D. A. (1990). Absorptive capacity: A new perspective on learning and innovation. Administrative Science Quartely, 35(1), 128-152.

Companhia Nacional de Abastecimento, CONAB. (2018). Acompanbamento Safra Brasileira - Grãos. Brasília: Companhia Nacional de Abastecimento, V.5 - Safra 2017/18 - N.5, Quinto Levantamento.

Dahlander, L., \& Gann, D. (2010). M. How open is Innovation? Research Policy, 39(6), 701.

Davis, A., \& Hobday, M. (2005). The business of projects: Managing innovation in complex products and systems. Cambridge, UK: Cambridge University Press. doi: 10.1017/ CBO9780511493294

De Mori, C. (2012). Capacidade tecnológica em sistemas agroindustriais: Proposição de indice e aplicação a empresas dos segmentos de trigo e leite. (Unpublished $\mathrm{PhD}$ thesis). Universidade Federal de São Carlos, São Paulo, Brazil.
Deschamps, J. P., \& Nelson, B. (2014). Innovation governance: How top management organizes and mobilizes for innovation. San Francisco, CA: Jossey \& Bass.

Dodgson, M. (2000). The management of technological innovation: An international and strategic approach. Oxford: Oxford University Press, 2(8), 102. doi: https://doi.org/ $10.3152 / 147154400781777368$

Dziura, M. J. (2001). Innovation: Sources and strategies. International Journal of Technology Management, 21, 5-6. doi: https://doi.org/ 10.1108/EUM0000000000026

Evanschitzky, H., Eisend, M., Calantone, R. J., \& Jiang, Y. (2012). Success factors of product innovation: an updated meta-analysis. Journal of Product Innovation Management, 29, 21-37. doi: https://doi.org/10.1111/j.15405885.2012.00964.x

Fischer, B. B., Schaeffer, P. R., \& Vanortas, N. S. (2018). Evolution of university-industry collaboration in Brazil from a technology upgrading perspective. Technological Forecasting and Social Change, 145, 330-340. doi: https:// doi.org/10.1016/j.techfore.2018.05.001

Frishammar, J., Söderholm, P., Bäckström, K., Hellsmark, H., \& Ylinenpää, H. (2014). The role of pilot and demonstration plants in technological development: Synthesis and directions for future research. Technology Analysis \& Strategic Management, 27(1), 1-18. doi: https://doi.org/10.1080/ 09537325.2014.943715

Freeman, C., \& Soete, L. (1997). The economics of Industrial Innovation. (3rd. ed.). Cambridge, Massachusetts: The MIT Press.

Ganguly, A. (1999). Business-driven research \& development: Managing knowledge to create wealth. West Lafayette, Indiana: First Ichor Business Books.

García-Manjón, J., \& Romero-Merino, E. (2012). Research, development, and firm growth. Empirical evidence from European top R\&D spending firms. Research Policy, 41 (6), 10841092. doi: https://doi.org/10.1016/ j.respol.2012.03.017 
Gatignon, H., \& Xuereb, J. M. (1997). Strategic orientation of the firm and new product performance. Journal of Marketing Research, 34(1), 77-90. doi: https://doi.org/10.2307/ 3152066

Goedhuys, M., \& Veugelers, R. (2012). Innovation strategies, process and product innovations and growth: Firm-level evidence from Brazil. Structural Change and Economic Dynamics, 23, 516-529. doi: https://doi.org/ 10.1016/j.strueco.2011.01.004

Guan, J. C., Mok, C. K., Yam, R. C. M., Chin, K. S. \& Pun, K. F. (2006). Technology transfer and innovation performance: Evidence from Chinese firms. Technological Forecasting and Social Change, 73(6), 666-678. doi: https://doi.org/10.1016/ j.techfore.2005.05.009

Guldbrandsen, M., \& Smeby, J. C. (2005). Industry funding and university professors' research performance. Research Policy, 34(6), 403-433.

Gupta, A. K., \& Singhal, A. (1993). Managing human resources for innovation and creativity. Research-Technology Management, 36(3), 41-48. doi: https://doi.org/10.1080/ 08956308.1993.11670902

Han, J. K., Kim, N., \& Srivastava, R. K. (1998). Market orientation and organization performance: Is innovation a missing link? Journal of Marketing, 62(4), 30-45. doi: https:// doi.org/10.1177/002224299806200403

Hill, J., \& Neely, A. (2006). Innovative capacity of firms: On why some firms are more innovative than others. Proceedings of the International Annual EurOMA Conference 2000, Ghent, Belgium.

Hoegl, M., Gibbert, M., \& Mazursky, D. (2008). Financial constraints in innovation projects: When is less more? Research Policy, 37(8), 13851388. doi: https://doi.org/10.1016/ j.respol.2008.04.018

Huselid, M. (1995). The impact of human resource management practices on turnover, productivity and corporate financial performance. Academy of Management Journal, $38,647-656$.

Instituto Brasileiro de Geografia e Estatística, IBGE. (2015). Demografia das empresas 2013. Rio de Janeiro, Estudos e Pesquisas: Informação Econômica, (25). Brasília: IBGE.
Janssen, O. (2000). Job demands, perceptions of effort-reward fairness and innovative work behavior. Journal of Occupational and Organizational Psychology, 73(3), 287-302, 2000. doi: https://doi.org/10.1348/ 096317900167038

Jarvis, V., \& Prais, S. (1995). The quality of manufactured products in Britain and Germany. London \& Berlin: National Institute of Economic and Social Research.

King, N., \& Anderson, N. R. (2002). Managing innovation and change: $A$ critical guide for organizations. London: Thompson Learning.

Koc, T., \& Ceylan, C. (2007). Factors impacting the innovative capacity in large-scale companies. Technovation, 27(3), 105-114. doi: https://doi.org/10.1016/ j.technovation.2005.10.002

Lee, C.-Y., Wu, H.-L., \& Pao, H.-W. (2014). How does $R \& D$ intensity influence firm explorativeness? Evidence of $\mathrm{R} \& \mathrm{D}$ active firms in four advanced countries. Technovation, 34(10), 582-593. doi: https://doi.org/ 10.1016/j.technovation.2014.05.003

Liefner, I., Si, Y.-F, \& Schäfer, K. (2019). A latecomer firm's R\&D collaboration with advanced country universities and research institutes: The case of Huawei in Germany. Technovation, 86-87, 3-14. doi: https://doi.org/ 10.1016/j.technovation.2019.03.002

Llórens-Montes, F. J., García-Morales, V. J., \& Verdú-Jover, A. J. (2004). The influence on personal mastery, organizational learning and performance of the level of innovation: Adaptive organization versus innovator organization. International Journal of Innovation and Learning, 1(2), 101-114. doi: https:// doi.org/10.1504/IJIL.2004.003714

Loof, H., \& Hesmati, A. (2002). Knowledge capital and performance heterogeneity: A firm-level innovation study. International Journal of Production Economics, 76(1), 61-85, 2002. doi: https://doi.org/10.1016/S09255273(01)00147-5

Martín-de-Castro, G. (2015). Knowledge management and innovation in knowledgebased and high-tech industrial markets: The role of openness and absorptive capacity. Industrial Marketing Management, 47, 143-146. doi: https://doi.org/10.1016/ j.indmarman.2015.02.032 
Martín-de-Castro, G., Delgado-Verde, M., NavasLópez, J. E., \& Cruz-González, J. (2013). The moderating role of innovation culture in the relationship between knowledge assets and product innovation. Technological Forecasting and Social Change, 80(2), 351-363. doi: http:// dx.doi.org/10.1016/j.techfore.2012.08.012

Organização para a Cooperação e Desenvolvimento Econômico, OCDE. (2006). Diretrizes para coleta e interpretaşão de dados sobre inovação. (Financiadora de Estudos e ProjetosFINEP, trad.). Brasília: OCDE- FINEP.

Palage, K., Lundmark, R., \& Söderholm, P. (2019). The impact of pilot and demonstration plants on innovation: The case of advanced biofuel patenting in the European Union. International Journal of Production Economics, 210, 42-45. doi: https:// doi.org/10.1016/j.ijpe.2019.01.002

Pfeffer, J. (1994). Competitive advantage through people. Boston, Mass.: Harvard Business School Press.

Pisano, G. P. (2015). You need an innovation strategy. Harvard Business Review, 93(6), 44-54.

Quadros, R. (2008) Aprendendo a inovar: padrões de gestão da inovação tecnológica em empresas industriais brasileiras. [Annals of research] Padrões de gestão da inovação tecnológica em empresas industriais brasileiras (pp. 1-24). Campinas, Brazil: Universidade Estadual de Campinas.

Quandt, C. O., \& Castilho, M. F. D. (2017). Relationship between collaboration and innovativeness: a case study in an innovative organization. International Journal of Innovation and Learning, 21(3), 257-273.

Salles-Filho, S. L. M., \& Bonacelli, M. B (2010). Trends in the organization of public research institutions: lessons from the Brazilian case. Science and Public Policy, 37(3), 193-204.

Saunila, M., Pekkola, S., \& Ukko, J. (2014). The relationship between innovation capability and performance: The moderating effect of measurement. International Journal of Productivity and Performance Management, 63, 234-249. doi: https://doi.org/10.1108/IJPPM-04-20130065
Schot, J. \& Steinmueller, W. E. (2018). Three frames for innovation policy: $R \& D$, systems of innovation and transformative change. Research Policy, 47, 1557-1559. doi: https:// doi.org/10.1016/j.respol.2018.08.011

Silva, F., Oliveira, E., \& Moraes, M. (2016). Innovation development process in small and medium technology-based companies. INMRInnovation \& Management Review, 13(3), 4-12. doi: https://doi.org/10.1016/j.rai.2016.04.005

Singuaw, J. A., Simpson, P. M., \& Enz, C. A. (2006). Conceptualizing innovation orientation: A framework for study and integration of innovation research. The Journal of Product Innovation Management, 23, 556-574.

Slater, S. F., Mohr, J. J., \& Sengupta, S. (2014). Radical product innovation capability: Literature review, synthesis, and illustrative research propositions. Journal of Product Innovation Management, 31(3), 552-566. doi: https://doi.org/10.1111/jpim.12113

Tidd, J. \& Bessant, J. (2015). Gestão da inovação. (5th. ed.). São Paulo: Bookman.

Tidd, J. \& Bessant, J., \& Pavitt, K. (2005). Managing innovation: Integrating technological, managerial organizational change, (3). New York: McGraw-Hill.

Tushman, M. A., Anderson, P., \& O’Reilly, C. A. (1997). Technology cycles, innovation streams and ambidextrous organizations: Organization renewal through innovations streams and strategic change. In M. A. Tushman \& P. Anderson (Orgs.), Managing strategic innovation [Chapter 1] (pp. 3-62). New York: Oxford University Press.

Zheng, M. (2011). The relationship between FDI technology spillovers and technology innovation: Effect of absorptive capability. Science Research Management, 32(3), 1-8.

Zhou, K. Z., Yim, C. K. \& Tse, D. K. (2005). The effects of strategic orientations on technology-and market-based breakthrough innovations. Journal of Marketing, 69, 42-60. doi: https://www.jstor.org/stable/30162044

Zornoza, C. C., Alcamí, R. L., Ciprés, M. S., \& Navarro, M. B. (2004). A Meta-analysis of innovation and organizational size. Organization Studies, 25(3), 335-337. doi: https:/ /doi.org/10.1177/0170840604040039 